\title{
UJI KARAKTERISTIK 4 JENIS RAMBUTAN LOKAL (Nephelium sp.)
}

\section{Characteristics Test of 4 Kinds of Local Rambutan (Nephelium sp.)}

\author{
Nur Hasanah Nasution, T. Rosmawaty, Mardaleni \\ Jurusan Agroteknologi FAPERTA-UIR Fakultas Pertanian Universitas Islam Riau \\ J1. Kaharuddin Nasution, No. 113, Perhentian Marpoyan, 28284, Pekanbaru, Riau, Indonesia \\ e-mail: Hasanah27@student.uir.ac.id \\ [Diterima: Agustus 2018; Disetujui: Desember 2018]
}

\begin{abstract}
The purpose of this study was to determine and compare the Morphological, Physical, Storage, and Chemical Characteristics of 4 types of Local Rambutan (Nephelium Sp.). Fruit characteristic test is carried out on Morphology, Physical Properties, Storing Power, and Chemical Content of Rambutan fruit which refers to Descriptor of Rambutan (IPGRI, 2003). This study uses one-way Anova Analysis which is then tested further by BNJ at a 5\% level for the Chemical Content Test of fruit. Followed by Klastering Test using MVSP 32 Program with Spearman Coefficient analysis. Morphological observations of fruit quantitatively and qualitatively that is Pulasan has the character of weight, length, diameter, skin weight, aryl weight, and weight of fruit seeds is greater than other types. Lulu has a uniform fruit skin color that is dark red, Sipadeh (N2) also has a uniform color that is yellow / cream. Sipadeh (N1) and Pulasan have a sweeter taste and easier idleness (chipped). This is different from Lulu and Sipadeh (N2), where both types have a sour taste and are difficult to crack (peel) from the seeds. In the chemical test, Sipadeh (N2) and Lulu have a high content of Vitamin C and total titrated acid. Whereas Pulasan and Sipadeh (N1) which have high Dissolved Solid Total Value. The results of the morphological cluster analysis of the fruit produced a dendrogram with a phenolic similarity of $-50 \%$ to $100 \%$. The results of the cluster chemical analysis result in a dendrogram with Kf $-80 \%$ to $70 \%$.
\end{abstract}

Keyword: Characteristics, Local Rambutan (Nephelium Sp.)

\begin{abstract}
ABSTRAK
Tujuan Penelitian untuk mengetahui dan membandingkan Karakteristik Morfologi, Fisik, Daya Simpan dan Kimiawi 4 jenis Rambutan Lokal (Nephelium Sp.). Uji Karakteristik buah dilakukan terhadap Morfologi, Sifat Fisik, Daya Simpan dan Kandungan Kimia buah Rambutan yang mengacu pada Descriptor of Rambutan (IPGRI, 2003). Penelitian ini menggunakan Analisis Anova oneway yang kemudian di uji lanjut BNJ pada taraf $5 \%$ untuk Uji Kandungan Kimia buah. Dilanjutkan dengan Uji Klastering menggunakan Program MVSP 32 dengan analysis Spearman Coefficient.Hasil pengamatan Morfologi buah secara kuantitatif dan kualitatif yaitu Pulasanmemiliki karakter berat, panjang, diameter, berat kulit, berat aril dan berat biji buah lebih besar dibanding jenis lainnya. Lulu memiliki warna kulit buah yang seragam yaitu berwarna merah gelap, Sipadeh (N2) juga memiliki warna seragam yaitu berwarna kuning/cream. Sipadeh (N1) dan Pulasan memiliki rasa yang lebih manis serta kelekangan arillebih mudah (ngelotok). Hal ini berbeda dengan Lulu dan Sipadeh (N2), dimana kedua jenis ini memiliki rasa yang masam dan sulit lekang (ngelotok) dari bijinya. Pada uji kandungan kimia Sipadeh (N2) dan Lulu memiliki kandungan Vitamin C dan Total Asam Tertitrasi yang tinggi.Sedangkan Pulasan dan Sipadeh (N1) yang memiliki Nilai Total Padatan Terlarut tinggi. Hasil analisis kluster Morfologi buah menghasilkan dendogram dengan Kemiripan fenotik -50\% sampai $100 \%$. Hasil analisis kluster kandungan kimia menghasilkan dendogram dengan Kf -80 \% sampai $70 \%$.
\end{abstract}

Kata Kunci : Karakteristik, Rambutan Lokal (Nephelium Sp.) 


\section{PENDAHULUAN}

Menurut Retnoningsih (2003)Indonesia
adalah salah satu negara mega biodiversitasyang mana memiliki kekayaan dan keanekaragaman sumber daya alam hayati tertinggi di dunia, jauh lebih tinggi dari pada Amerika Latin dan Afrika Tropis, tetapi kekayaan tumbuhan yang ada di Indonesia masih belum dipelajari dan dimanfaatkan dengan baik oleh bangsa Indonesia. Hal ini dapat dilihat banyaknyareferensi-referensi tentang tumbuhan Indonesia yang ditulis oleh penulis asing dan penelitian tumbuhan di daerah tropika justru banyak dilakukan oleh penelitipeneliti asing (Prihanta, 2004).

Penelitian terhadap rambutan dan Pulasan sudah banyak dilakukan baik untuk mengukur tingkat keragaman buah ataupun potensi dari buah itu sendiri (Siti Nurhayati, 2004; Lydia, dkk. 2001; Victoria Hawarima dan Ety Apriliana, 2016). Untuk rambutan jenis Sipadeh (N1), Sipadeh (N2) dan rambutan Lulu tidak banyak dilakukan penelitian karena jenis ini merupakan jenis lokal yang belum dikembangkan secara luas pada masyarakat.

Tiap jenis dari buah rambutan memiliki karakteristik fisik dan kimia yang beragam sehingga membuat jumlah kandungan zat yang terdapat didalamnya juga beragam. Untuk uji karakteristik Fisik dilihat dari segi Morfologi Buah Siap Panen, Uji Organoleptik buah dan Daya Simpan Buah, sedangkan untuk Uji karakteristik Kimia dilakukan untuk melihat Total Padatan Terlarut $\left({ }^{0}\right.$ Brix $)$ buah, kandungan vitamin $\mathrm{C}(\mathrm{mg})$, dan total asam terlarut (TAT) pada 4 jenis rambutan lokal diantaranya Sipadeh (N1), Sipadeh (N2), Lulu dan Pulasan.

Karakter morfologi siap panen ditandai dengan warna buah yang mengalami perubahan dari hijau menjadi berwarna merah segar untuk jenis Lulu dan Pulasan, untuk jenis Sipadeh (N1) berwarna kuning kemerahan dan Sipadeh (N2) berwarna kuning atau cream.

Pada buah yang masak fisiologis akan mengalami proses respirasi dan menyebabkan perubahan pada fisik buah serta pembusukan pada buah. Oleh karena itu, penanganan pasca panen terhadap buah segar rambutan perlu dilakukan, hal ini bertujuan untuk mengetahui daya simpan buah baik secara genetik maupun dengan adanya perlakuan kemasan pada buah. Penelitian terhadap tingkat kematangan dan daya simpan buah rambutan Rapiah, pernah dilakukan (Soenaryono, H. dkk. 1982; Sosrodiharjo S, 1991; Broto, 1990).Oleh sebab itu, perlu dilakukan suatu kajian untuk mendapatkan lama daya simpan dari jenis buah rambutan lainnya (Sipadeh (N1), Si Padeh (N2), Lulu dan Pulasan).

\section{METODE PENELITIAN}

Penelitian ini telah dilaksanakan di Laboratorium Bioteknologi Universitas Islam Riau, Jalan Kaharuddin Nasution km 11, Kelurahan Air Dingin, Kecamatan Bukit Raya, Kota Pekanbaru, Riau. Penelitian ini telah dilaksanakan selama 3 bulan dimulai dari Desember 2017 sampai dengan Februari 2018.

Bahan yang digunakan dalam penelitian ini adalah4 Jenis buah Rambutan lokal, diantaranya: Jenis Sipadeh (N1), Sipadeh (N2), Lulu, dan Pulasan, Iodine 0,01 N, NaOH $0.1 \mathrm{~N}$, Indikator PP, amilum, kertas saring, sarung tangan, masker, tissue dan air aquadesh. Sedangkan alat yang digunakan adalah Timbangan Analitik, Healt Magnetic Strirrer, Buret dan Statif, Hand Refraktometer, blender, jangka sorong, karet penghisap, pipet volume, pipet tetes, beaker gelas, gelas ukur, tabung ukur, teko, pisau, kamera dan alat tulis.

Penelitian ini dilakukan denganmenggunakan 4 jenis rambutan lokal, diantaranya: Rambutan Sipadeh (N1), Rambutan Sipadeh (N2), Rambutan Lulu, dan Pulasan. Uji Karakteristik buah ini dilakukan terhadap Morfologi, Sifat Fisik, Daya Simpan dan Kandungan Kimia buah Rambutan yang mengacu pada Descriptor of Rambutan (IPGRI, 2003). Penelitian ini menggunakan Analisis Anova oneway yang kemudian di uji lanjut BNJ (Beda Nyata Jujur) pada taraf $5 \%$ untuk Uji Kandungan Kimia buah. Dilanjutkan dengan Uji Klastering menggunakan Program MVSP 32 yang ditampilkan dalam bentuk dendogram dengan analysis Spearman Coefficient.

Buah sampel yang digunakan adalah buah masak fisiologis yang secara langsung dipanen dari pohon rambutan dan langsung dianalisis di Laboratorium Bioteknologi Universitas Islam Riau. Keempat jenis 
rambutan local ini didapatkan dari Kabupaten Kampar dan Kabupaten Pelalawan.

Pengamatan terhadap karakter morfologi dilakukan berdasarkan Buku Panduan Deskriptor Rambutan (IPGRI 2003). Pengamatan dilakukan terhadap karakterkarakter yang terdapat pada buah, daya simpan dan kandungan kimia rambutan. Data pengamatan karakter morfologi disajikan dalam bentuk Deskriptif dan juga skoring.

\section{Karakter Morfologi 4 Jenis Rambutan Lokal di Riau}

Hasil Pengamatan morfologi 4 Jenis Rambutan Lokal di Riau mengidentifikasi 4 jenis rambutan yaitu: Sipadeh (N1), Sipadeh (N2), Lulu, dan Pulasan. Berikut disajikan ciri khas 4 jenis rambutan lokal Riau pada Tabel 1 berikut:

\section{HASIL DAN PEMBAHASAN}

Tabel 1. Ciri Khas 4 Jenis Rambutan Lokal secara umum

\begin{tabular}{cll}
\hline No & \multicolumn{1}{c}{ Kultivar } & \multicolumn{1}{c}{ Ciri Khas } \\
\hline 1 & Sipadeh (N1) & $\begin{array}{l}\text { Bentuk Bulat telur, Rambut Panjang, Sedang, kulit buah tipis, crispy, kandungan air } \\
\text { Juicy, aril tebal, dan ngelotok. }\end{array}$ \\
\hline 2 & Sipadeh (N2) & $\begin{array}{l}\text { Bentuk Bulat, Rambut Panjang, Padat, kulit buah tipis, kenyal, kandungan air Juicy, } \\
\text { aril tipis, dan tidak ngelotok. }\end{array}$ \\
\hline 3 & Lulu & $\begin{array}{l}\text { Bentuk Bulat, Rambut Pendek, Padat, kulit buah tipis, kenyal, kandungan air Juicy, } \\
\text { aril tipis, dan tidak ngelotok }\end{array}$ \\
\hline 4 & Pulasan & $\begin{array}{l}\text { Bentuk Bulat, Rambut Panjang, Padat, kulit buah tebal, kenyal, kandungan air sangat } \\
\text { berair, aril tipis, dan kurang ngelotok. }\end{array}$ \\
\hline
\end{tabular}

\section{Karakter Morfologi buah Kuantitatif}

Karakterisasi morfologi ini dilakukan berdasarkan Descriptor of Rambutan yang Tabel 2. Rerata Morfologi buah kuantitatif

\begin{tabular}{lcccc}
\hline \multirow{2}{*}{ Parameter Pengamatan } & \multicolumn{4}{c}{ Jenis } \\
\cline { 2 - 5 } & Sipadeh (N1) & Sipadeh (N2) & Lulu & Pulasan \\
\hline Berat buah $(\mathrm{g})$ & 9,74 & 8,20 & 7,68 & 22,54 \\
Panjang buah $(\mathrm{cm})$ & 1,75 & 1,64 & 1,66 & 2,57 \\
Diameter buah $(\mathrm{cm})$ & 1,43 & 1,31 & 1,27 & 2,19 \\
Berat Kulit buah $(\mathrm{g})$ & 3,80 & 3,74 & 3,30 & 14,27 \\
Panjang rambut $(\mathrm{mm})$ & 0,65 & 0,62 & 0,34 & 0,29 \\
Berat Aril buah $(\mathrm{g})$ & 7,88 & 6,35 & 6,38 & 14,98 \\
Berat Biji buah $(\mathrm{g})$ & 0,39 & 0,39 & 0,39 & 0,72 \\
\hline
\end{tabular}

disusun oleh International Plant Genetic Resources Institute (IPGRI, 2003). Hasil Pengamatan terhadap karakter Morfologi buah inidapat di lihat pada Tabel 2 berikut ini:
Menurut Pendapat Siti Nurhayati (2004), berat buah berhubungan erat dengan proses fisiologi pada buah. Seperti yang dikemukakan oleh Wills et al. (1981), Buah yang berwarna hijau masih mengalami proses perkembangan lebih lanjut. Buah rambutan termasuk pada pola non klimaterik, sehingga tahap perkembangan buah diawali dengan pembelaan sel, pendewasaan sel, pematangan dan penuaan.

Menurut Simmond etal. (1998), berat daging buah pada permulaan perkembangan buah sangat rendah, sedangkan berat kulit sangat tinggi. Dengan semakin masaknya buah berat daging bertambah disertai sedikit demisedikitpengurangan berat kulitnya,yang disebabkanoleh selulosadan hemiselulosa pada pati.

1.1.1 Analisis Kluster Morfologi buah secara Kuantitatif 4 jenis rambutan lokal di Riau

Hubungan kekerabatan Morfologi buah secara Kuantitatif dianalisis menggunakan aplikasi MVSP 32.00 menggunakan cluster analysis Spearman Coefficient, hasil analisis dapat dilihat pada gambar 2 dibawah ini: 


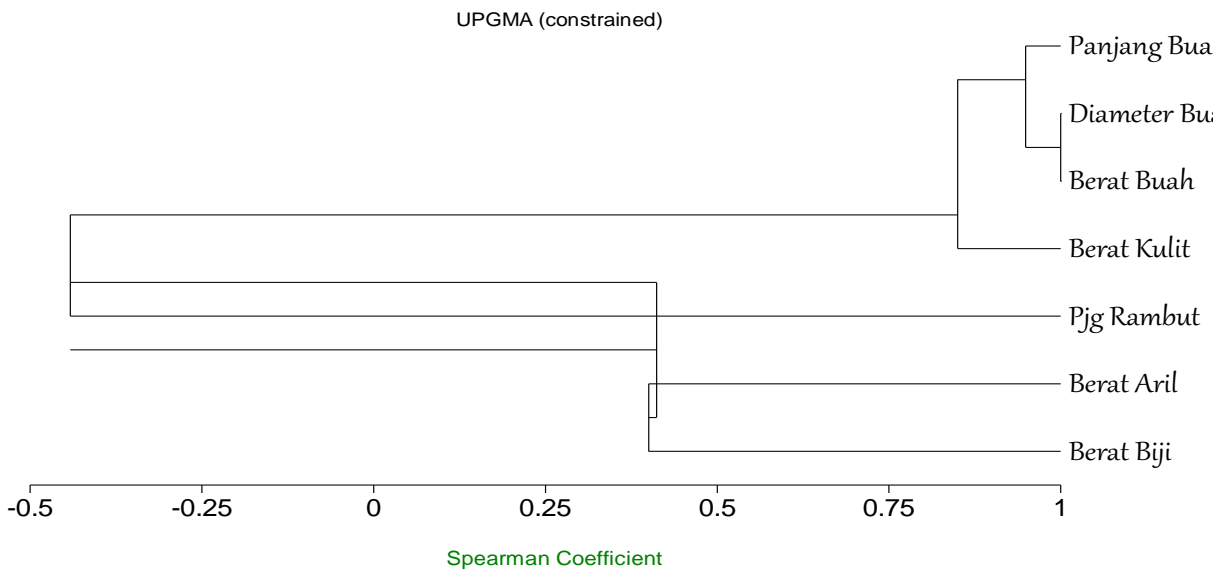

Gambar 1. Dendogram Analisa/kemiripan Morfologi 4 jenis rambutan berdasarkancluster analysis menurut Spearman Coefficient

Dari hasil analisis kluster Morfologi buah secara Kuantitatif 4 jenis rambutan lokal di Riau dari 7 Karakter Morfologi buah menghasilkan dendogram dengan koefisien kemiripan (Kf) $-50 \%$ s/d $100 \%$. Keseluruhan rambutan bersatu pada kemiripan $-50 \%$, yang terbagi atas tiga kelompok utama.

Kelompok I memiliki Kf antara $70 \%$ s/d $100 \%$ pada 4 karakter diantaranya panjang, diameter, berat dan berat kulit buah. Pada kelompok I untuk karakter diameter dan berat buah memiliki korelasi Positif dengan nilai Kf mencapai $100 \%$ yang mengartikan bahwa kedua karakter memiliki hubungan yang sangat erat, sehingga dapat ditarik kesimpulan bahwa jika nilai diameter buah meningkat maka nilai berat buah akan mengalami peningkatan. Untuk Panjang dan diameter serta berat buah memiliki korelasi Positif dengan nilai Kf mencapai 90 \% yang mengartikan bahwa ketiga karakter memiliki hubungan yang sangat erat, sehingga dapat ditarik kesimpulan bahwa jika nilai Panjang buah meningkat maka nilai diameter dan berat buah akan mengalami peningkatan. Untuk karakter berat kulit buah memiliki nilai Kf sebesar $80 \%$ yang mengartikan bahwa jika nilai berat kulit buah mengalami peningkatan maka akan mempengaruhi nilai peningkatan terhadap karakter panjang, diameter dan berat buah.

Kelompok II terbentuk pada Kf dengan taraf nilai $-50 \%$ atas 1 karakter yakni panjang rambut buah yang mengartikan bahwa karakter tersebut memiliki korelasi negative dengan dengan 6 karakter teruji lainnya. Sedangkan untuk Kelompok III terbentuk pada Kf dengan nilai antara $25 \%-50 \%$ atas 2 karakter diantaranya berat aril dan berat biji buah yang mengartikan bahwa kedua karakter memiliki hubungan yang modrat/sedang, sehingga dapat ditarik kesimpulan bahwa jika nilai berat arilmengalami peningkatan maka nilaiberat biji buah akan mengalami peningkatan.

Nilai matriks tersebut menunjukkan semakin besar angka yang dihasilkan maka semakin tinggi kemiripan yang dimiliki oleh karakter, artinya semakin besar angka yang dihasilkan maka semakin tinggi korelasi persentase kekerabatan hubungan antara karakter. Sebaliknya, semakin kecil angka yang dihasilkan maka tingkat kemiripan yang dimiliki karakter tersebut semakin rendah artinya semakin rendah angka yang dihasilkan maka semakin rendah korelasi persentase kekerabatan hubungan antara karakter atau dianggap tidak ada ikatan ataupun hubungan korelasi (Frisia Situmorang, et al, 2013).

\section{Deskripsi Karakter Morfologi buah secara Kualitatif}

Peubah yang diambil berdasarkan scoring yang dinilai sendiri oleh peneliti berdasarkan standar IPGRI.Hasil deskripsi karakter morfologi buah secara kualitatif disajikan dalam bentuk grafik berikut ini. 


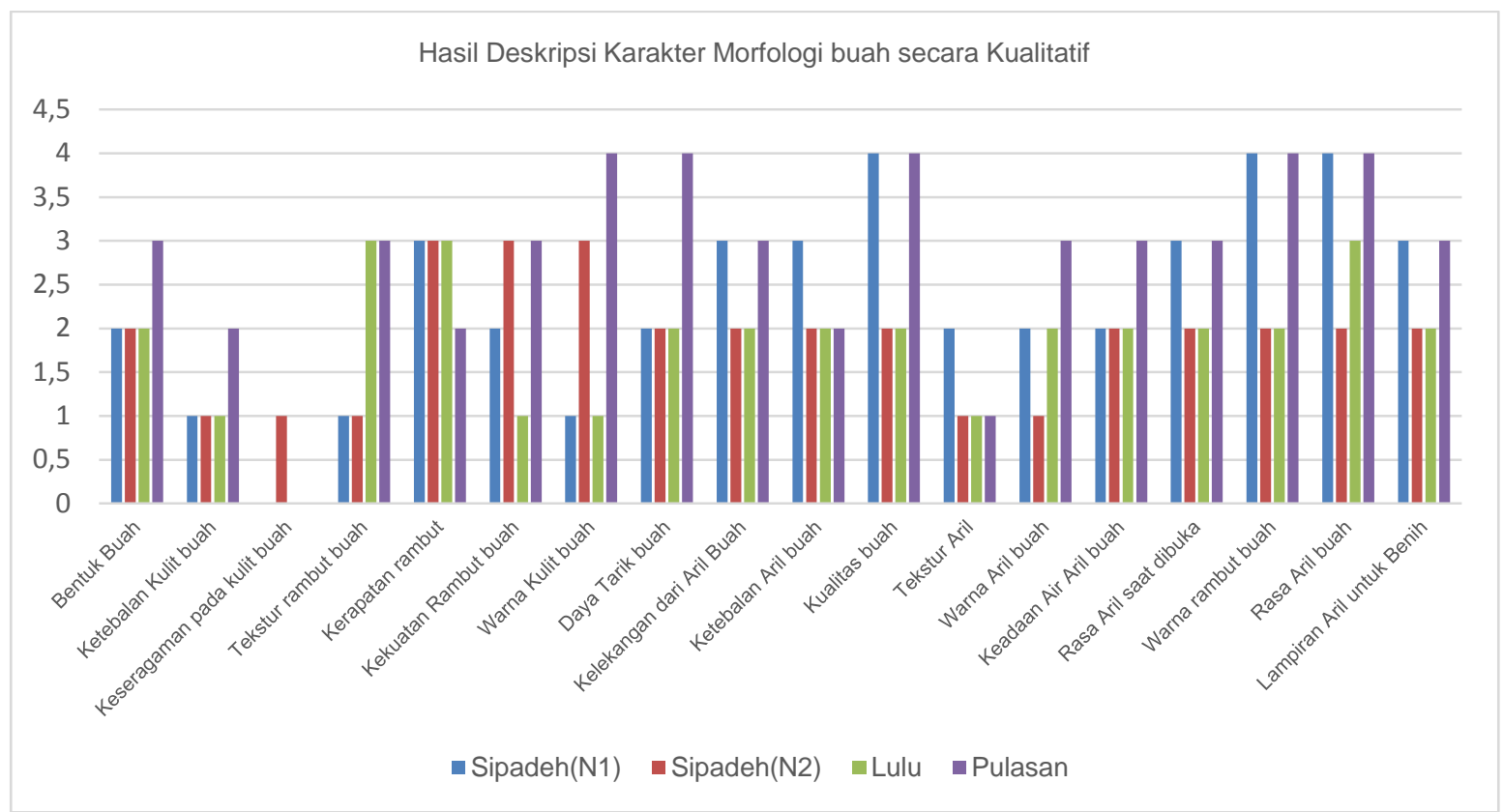

Grafik 1. Hasil skoring deskripsi karakter morfologi buah secara Kualitatif.

Penilaian dilakukan pada buah segar yang sudah memenuhi kriteria panen. Dari grafik diatas dapat ditarik kesimpulan bahwa deskripsi karakter morfologi buah secara kualitatif pada keempat jenis rambutan lokal ini memiliki fenotip yang relatif berbeda. Rambutan Lulu memiliki warna kulit buah yang seragam saat panen yaitu berwarna merah gelap, hal tersebut bersamaan dengan rambutan Sipadeh (N2) dimana pada saat dilakukan pemanenan warna kulit buah juga seragam yaitu berwarna kuning/cream. Dari segi kualitas buah pada keempat jenis rambutan lokal yang dinilai berdasarkan tingkat kemanisan dan kelekangan aril dari biji (ngelotok), Sipadeh (N1) dan Pulasan memiliki rasa yang lebih manis serta kelekangan aril yang relatif lebih mudah lekang (ngelotok). Hal ini berbeda dengan jenis Lulu dan Sipadeh (N2), dimana kedua jenis rambutan ini memiliki rasa yang masam dan sulit lekang (ngelotok) dari bijinya.

Hal diatas sesuai dengan pernyataan Casas, et al. (1999), yang menyatakan bahwa penyebab adanya variasi morofologi pada tanaman telah dijelaskan oleh para ahli yaitu dipengaruhi oleh faktor genetik dan lingkungan. Faktor lingkungan yang berpengaruh meliputi suhu, penyinaran matahari, curah hujan, tipe vegetasi dan teknik budidaya. Kondisi tanah juga sangat berpengaruh terutama kesuburan (ketersediaan unsur hara, air tanah) dan salinitas tanah.

\section{Daya Simpan Buah Rambutan}

Uji daya simpan pada 4 jenis buah rambutan ini bertujuan untuk mengetahui berapa lama waktu efisien dalam penyimpanan buah serta waktu konsumsi buah rambutan untuk tetap menjaga kualitas dari buah masingmasing jenis rambutan. Hasil uji daya simpan masing-masing 4 jenis buah rambutanini bisa dilihat pada Gambar 2 dan Gambar 3 berikut ini. Dari Gambar 2 hasil deskripsi pada Daya Simpan buah terhadap warna buah dan Pembrowningan kulit buah dapat ditarik kesimpulan bahwa: Pada Jenis Sipadeh (N1) jenis perlakuan terbaik terdapat pada Wadah Karung yang memiliki kondisi warna kulit buah awal, dengan pembrowningan yang mulai terjadi pada hari ketiga masa penyimpanan. Untuk jenis Sipadeh (N2) jenis perlakuan terbaik terdapat pada Wadah Plastik yang memiliki kondisi warna kulit buah awal, dengan pembrowningan yang mulai terjadi pada hari keempat masa penyimpanan.

Untuk jenis Lulu jenis perlakuan terbaik terdapat pada Wadah Karung yang memiliki kondisi warna kulit buah awal, dengan pembrowningan yang mulai terjadi pada hari 
ketiga masa penyimpanan. Sedangkan untuk Pulasan jenis perlakuan terbaik terdapat pada Wadah Karung yang memiliki kondisi warna kulit buah awal, dengan pembrowningan yang mulai terjadi pada hari ketiga masa penyimpanan. Selain dari pengamatan perubahan warna dan kulit buah yang terjadi berikut juga disajikan hasil pengamatan Daya Simpan buah terhadap Perubahan Tekstur aril (daging buah) dan jumlah bagian daging buah yang dapat dimakan. Hasil pengamatan tersebut dapat dilihat pada Gambar 3 dibawah ini.
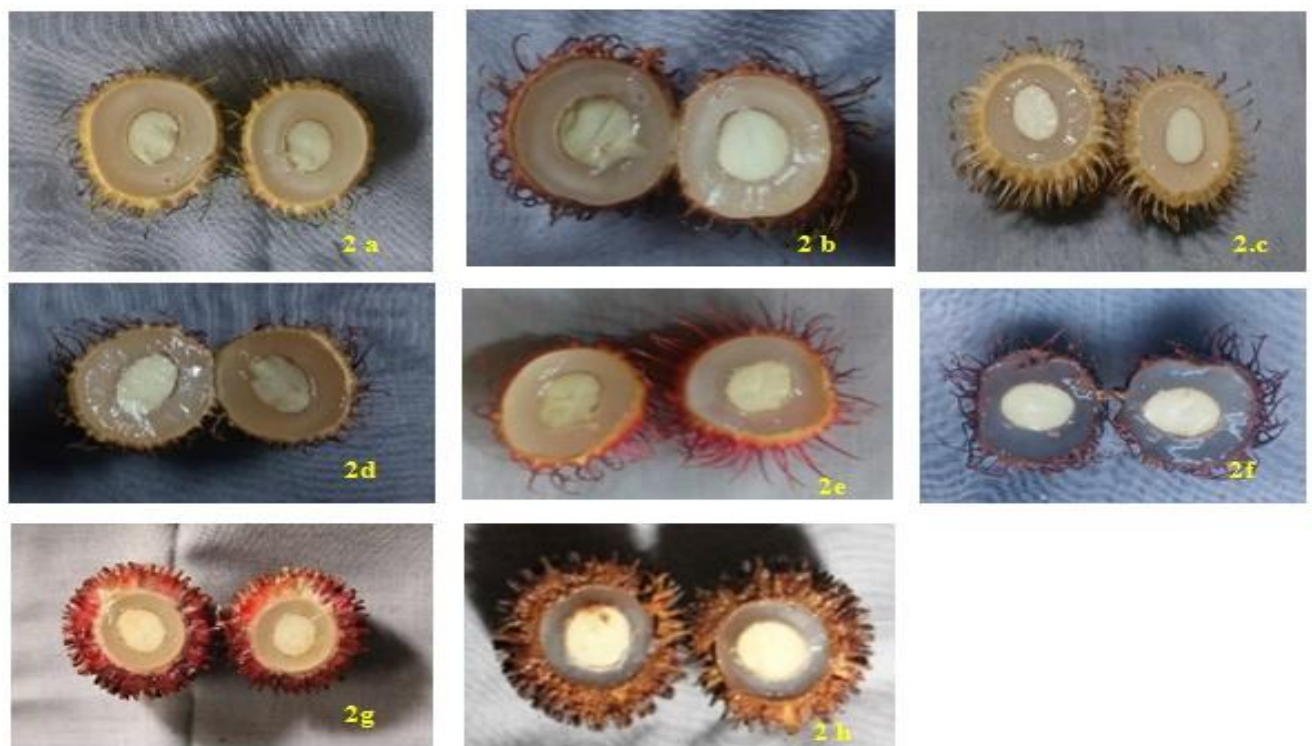

Gambar 2. Pencoklatan pada kulit buah

2a Buah Segar Sipadeh (N1)

2b Pencoklatan pada Hari ke-3 Sipadeh (N1)

2c Buah Segar Sipadeh (N2)

2d Pencoklatan pada Hari ke-4 Sipadeh (N2)

2e Buah Segar Lulu

2f Pencoklatan pada Hari ke-3 Lulu

2g Buah Segar Pulasan

2h Pencoklatan pada Hari ke-4 Pulasan
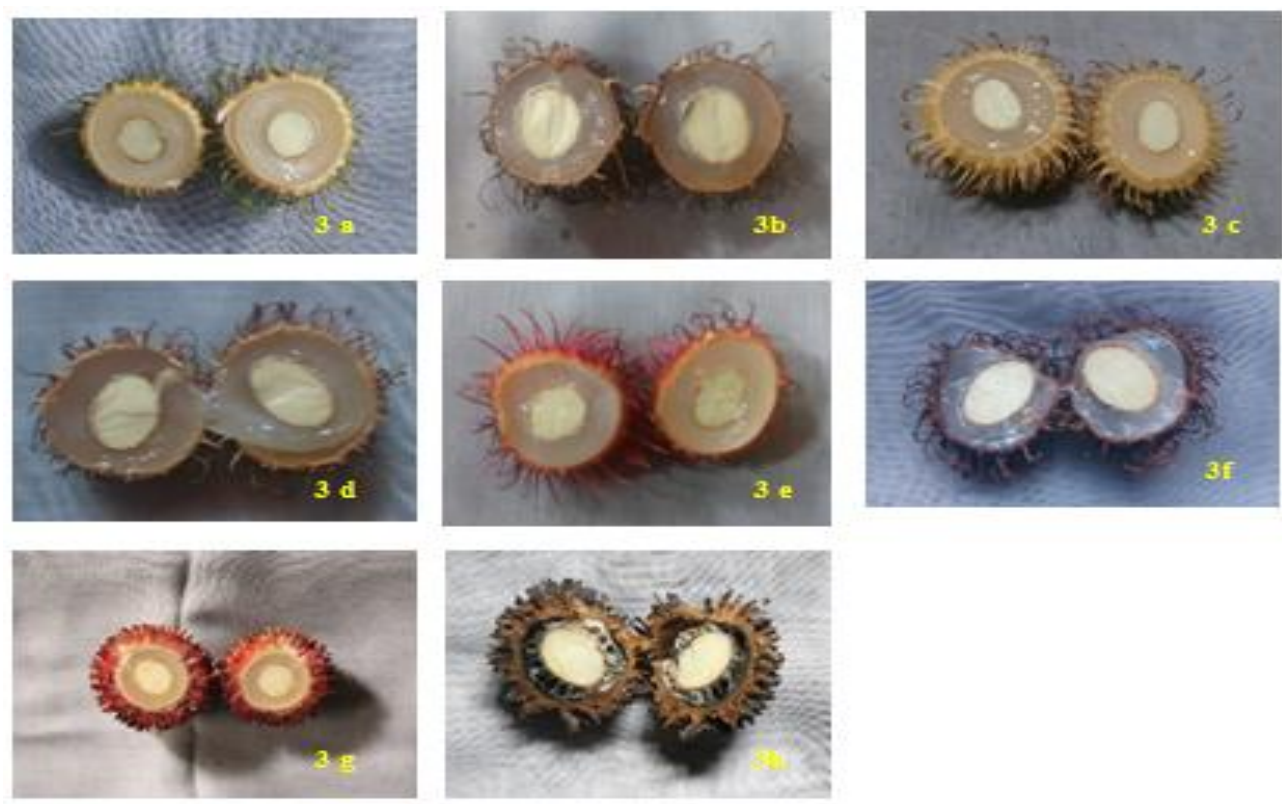

Gambar 3. Perubahan Daging buah rambutan saat disimpan

3a Sipadeh (N1) hari 1 Penyimpanan 3c Sipadeh (N2) hari 1 Penyimpanan 3e Lulu hari ke-1 Penyimpanan 3g Pulasan hari ke-1 Penyimpanan 3b Sipadeh (N1) hari 5 Penyimpanan 3d Sipadeh (N2) hari 5 Penyimpanan 3f Lulu hari ke-5 Penyimpanan 3h Pulasan hari ke-5 Penyimpanan 
Dari Gambar 3 dapat ditarik kesimpulan bahwa keseluruhan jenis rambutan pada daya simpannya memberikan pengaruh yang dapat dilihat dari warna kulit buah, pembrowningan, warna aril buah dan tekstur aril buah. Jenis Sipadeh (N1) buah yang mampu dikonsumsi setelah masa penyimpanan adalah buah yang disimpan pada hari ke-3 pada perlakuan wadah karung, sedangkan untuk Sipadeh (N2) buah yang mampu dikonsumsi setelah masa penyimpanan adalah buah yang disimpan pada hari ke-4 pada perlakuan wadah plastik. Selanjutnya, pada jenis Lulu buah yang mampu dikonsumsi setelah masa penyimpanan adalah buah yang disimpan pada hari ke-3 pada perlakuan wadah karung. Sementara itu, untuk Pulasan buah yang mampu dikonsumsi setelah masa penyimpanan adalah buah yang disimpan pada hari ke-3 pada perlakuan wadah karung.

Perubahan tekstur buah terjadi dikarenakan Oksidasi Pektin dimana saat proses pematangan pektin oleh enzim Metilesterase dan Poligakturose yang tidak mampu lagi mengikat air pada buah rambutan sehingga air yang keluar semakin besar dan mengakibatkan tekstur buah menjadi lunak. Kehilangan bobot komoditi hortikultura bukan saja diakibatkan oleh penguapan air tetapi juga oleh hilangnya gas $\mathrm{CO} 2$ hasil respirasi. Kehilangan air selama penyimpanan tidak hanya menurunkan berat, tetapi juga menurunkan mutu dan menimbulkan kerusakan (Muchtadi,1992).

\section{Kandungan Kimia Buah Rambutan}

Hasil Pengamatan terhadap Uji Kandungan Kimia Buah Rambutan, setelah dianalisis ragam menunjukan bahwa perlakuan berbagai jenis rambutan memberikan pengaruh untuk semua Parameter Pengamatan kandungan kimia buah rambutan. Rerata hasil pengamatan Uji Kandungan Kimia Buah Rambutan setelah di Uji Lanjut BNJ pada taraf $5 \%$ dapat di lihat pada Tabel 3 berikut ini.

Tabel 3. Rerata Uji Kandungan Kimia buah Rambutan

\begin{tabular}{|c|c|c|c|c|c|c|}
\hline \multirow{2}{*}{$\begin{array}{c}\text { Parameter } \\
\text { Pengamatan }\end{array}$} & \multicolumn{4}{|c|}{ Perlakuan } & \multirow{2}{*}{ KK } & \multirow{2}{*}{ BNJ P } \\
\hline & Sipadeh (N1) & Sipadeh (N2) & Lulu & Pulasan & & \\
\hline $\begin{array}{l}\text { Total Padatan } \\
\text { Terlarut }\left({ }^{0} \text { Brix }\right)\end{array}$ & $12,53 \mathrm{~b}$ & $7,00 \mathrm{~d}$ & $8,30 \mathrm{c}$ & $20,47 \mathrm{a}$ & 0,7 & 0,93 \\
\hline $\begin{array}{l}\text { Total Asam } \\
\text { Tertitrasi (TAT) }\end{array}$ & $25,34 \mathrm{c}$ & $72,96 \mathrm{~b}$ & 119,4 a & $35,90 \mathrm{c}$ & 3,0 & 2,04 \\
\hline Vitamin $\mathrm{C}(\mathrm{mg})$ & $1,76 \mathrm{~b}$ & $2,75 \mathrm{a}$ & $2,79 \mathrm{a}$ & $1,47 \mathrm{~b}$ & 3,6 & 0,76 \\
\hline
\end{tabular}

Angka-angka pada baris dan kolom yang diikuti oleh huruf kecil yang sama tidak berbeda nyata menurut Uji Lanjut BNJ pada taraf $5 \%$.

Dari tabel 3 dapat diuraikan bahwa nilai tertinggi Total Padatan Terlarut $\left({ }^{0}\right.$ Brix $)$ terdapat pada Pulasan yakni 20.47 ( ${ }^{0}$ Brix) dan berbeda nyata dengan jenis lainnya, sedangkan untuk nilai terendah terdapat pada Sipadeh (N2) yakni 7.00. Padatan total terlarut pada buah dapat dipakai sebagai ukuran untuk menentukan tingkat kematangan buah karena kandungan gula dalam buah meliputi $80 \mathrm{~s} / \mathrm{d} 85 \%$ dan ini akan menentukan kualitas buah tersebut. Jumlah padatan total terlarut maksimal terjadi saat substrat berupa senyawa gula kompleks masih banyak tersedia karena ensim pemecah aktivitasnya juga masih tinggi. Di pihak lain, senyawa gula komplek, pektin terlarut terjadi dengan terbentuknya air karena pemecahan pati. Pektin terlarut terbentuk dalam jumlah besar, sehingga jumlah padatan total terlarut mencapai maksimum (Noor Harini, 1993, Haryanti et al, 1991). Daging buah yang masih mentah memiliki rasa sepat yang disebabkan oleh senyawa tannin. Selama proses pemasakan buah rasa apet berangsur-angsur kurang, hal ini disebabkan kandungan tannin aktif menurun pada buah yang masak (Stover, 1987).

Total Asam Tertitrasi nilai tertinggi terdapat pada Lulu yakni $119.4(\mathrm{mg} / 100)$ dan berbeda nyata dengan jenis lainnya, sedangkan nilai terendah terdapat pada Sipadeh (N1) yakni 25.34 (mg/100). Mahisworo et all., (1989) mengatakan bahwa susunan kandungan kimiawi dari daging buah rambutan sangat tergantung pada jenis, kesuburan tanah tempat 
tumbuh dan banyaknya sinar matahari yang di dapat, curah hujan dan lain-lain.

Nilai Tertinggi Vitamin $\mathrm{C}$ terdapat pada Lulu yakni $2.79(\mathrm{mg})$ dan tidak berbeda nyata dengan Sipadeh (N2) sebanyak 2.75 (mg), Pada jenis rambutan lulu dan Sipadeh (N2) dengan tingkat kematangan yang sama memiliki rasa asam yang dominan. Sedangkan nilai terendah terdapat pada jenis Pulasan yakni 1.47 (mg), hal ini dikarenakan jenis pulasan cenderung memiliki rasa yang manis sehingga kadar asamnya terkandung lebih sedikit.

\section{Analisis Kluster Kandungan Kimia buah 4 jenis rambutan lokal di Riau}

Hubungan kekerabatan 4 jenis rambutan lokal di Riau dapat dilihat dari hasil analisis Kluster yang telah dilakukan. Analisis ini dilakukan dengan aplikasi MVSP 32.00 menggunakan cluster analysis Spearman Coefficient, hasil analisis dapat dilihat pada gambar 4 dibawah ini

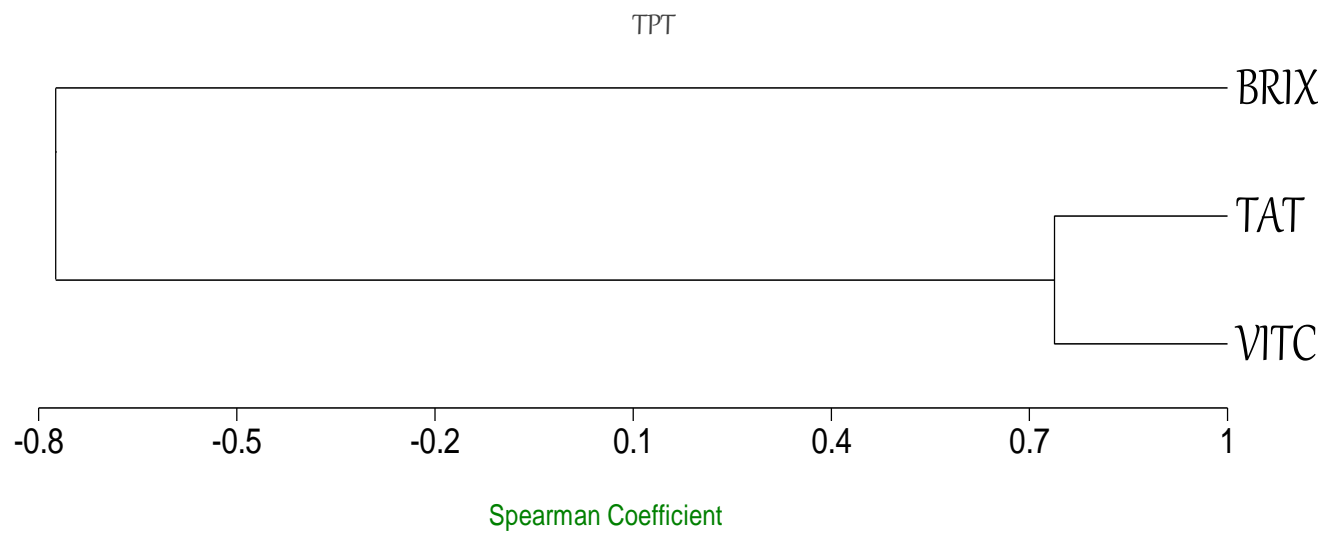

Gambar 4. Dendogram Analisa/kemiripan Kandungan Kimia 4 jenis rambutan berdasarkancluster analysis menurut Spearman Coefficient.

Dari hasil analisis kluster kandungan kimia 4 jenis rambutan lokal di Riau dari 3 Karakter kimia menghasilkan dendogram dengan koefisien kemiripan $-80 \%$ s/d $100 \%$. Keseluruhan rambutan bersatu pada kemiripan $80 \%$. Hasil analisis dendogram ini terbentuk 2 kelompok utama yang masing-masing terbagi menjadi kelompok I dan kelompok II.

Kelompok I terbentuk pada Kf dengan taraf antara $70 \%$ s/d $100 \%$ yang terdiri atas karakter Total Asam Terlarut (TAT) dan Vitamin $\mathrm{C}$, yang menandakan bahwa jika nilai TAT meningkat maka nilai vitamin $\mathrm{C}$ yang terkandung juga akan mengalami peningkatan. Kelompok II terbentuk pada Kf dengan taraf antara $-80 \%$ s/d $50 \%$ antara karakter Total Padatan Terlarut ( ${ }^{0}$ Brix) dengan TAT dan Vitamin C Sehingga dapat ditarik kesimpulan bahwa jika nilai total padatan terlarut ( ${ }^{\circ}$ Brix) meningkat maka nilai TAT dan Vitamin $\mathrm{C}$ yang terkandung akan mengalami penurunan dalam jumlah nilai yang dihasilkan.

\section{KESIMPULAN DAN SARAN}

\section{Kesimpulan}

1. Hasil pengamatan Karakter Morfologi buah secara kuantitatif semua jenis rambutan memiliki perbedaan karakterantar jenis, dimana Pulasanmemiliki karakter berat, panjang, diameter, berat kulit, berat aril dan berat biji buah lebih besar dibanding jenis lainnya. Lulu memiliki ukuran karakter dengan nilai paling kecil jika dibandingkan dengan keseluruhan jenis rambutan.

2. Lulu memiliki warna kulit buah yang seragam saat panen yaitu berwarna merah gelap, hal tersebut bersamaan dengan rambutan Sipadeh (N2) dimana pada saat dilakukan pemanenan warna kulit buah juga seragam yaitu berwarna kuning/cream. Dari segi kualitas buah pada keempat jenis rambutan yang dinilai berdasarkan tingkat kemanisan dan kelekangan aril dari biji, Sipadeh (N1) dan Pulasan memiliki rasa 
yang lebih manis serta kelekangan aril yang relatif lebih mudah lekang (ngelotok). Hal ini berbeda dengan jenis Lulu dan Sipadeh (N2), dimana kedua jenis rambutan ini memiliki rasa yang masam dan sulit lekang (ngelotok) dari bijinya.

3. Pada uji kandungan kimia menunjukan bahwa Sipadeh (N2) dan Lulu memiliki kandungan Vitamin C dan Total Asam Tertitrasi yang tinggi menandakan rasa Asam yang tinggi, berbeda dengan Pulasan dan Sipadeh (N1) yang memiliki Nilai Total Padatan Terlarut tinggi yang menandakan buah memiliki rasa yang dominan lebih manis dibandingkan dengan Sipadeh (N2) dan Lulu.

4. Jenis Sipadeh (N1) buah yang mampu dikonsumsi setelah masa penyimpanan adalah buah yang disimpan pada hari ke-3 pada perlakuan wadah karung, sedangkan untuk Sipadeh (N2) buah yang mampu dikonsumsi setelah masa penyimpanan adalah buah yang disimpan pada hari ke-4 pada perlakuan wadah plastik. Selanjutnya, pada jenis Lulu buah yang mampu dikonsumsi setelah masa penyimpanan adalah buah yang disimpan pada hari ke-3 pada perlakuan wadah karung. Sementara itu, untuk Pulasan buah yang mampu dikonsumsi setelah masa penyimpanan adalah buah yang disimpan pada hari ke-3 pada perlakuan wadah karung.

5. Hasil analisis kluster Morfologi buah menghasilkan dendogram dengan $\mathrm{Kf}-50 \%$ sampai $100 \%$. (Gambar4.2.). Keseluruhan rambutan bersatu pada kemiripan $-50 \%$ dan membentuk 3 kelompok utama, dengan 2 kelompok clustering antar jenis rambutan dengan Nilai (Kf) tertinggi $100 \%$ dan Nilai Kf Terendah $-50 \%$. Hasil analisis kluster kandungan kimia menghasilkan dendogram dengan Kf $-80 \%$ sampai $70 \%$ (Gambar 4.7.). Keseluruhan rambutan bersatu pada kemiripan -80\% membentuk 2 kelompok utama, dengan 2 kelompok clustering antar jenis rambutan dengan Nilai (Kf) tertinggi antara $70 \%-100 \%$ dan Nilai Kf Terendah yaitu $-80 \%$.

\section{Saran}

1. Penyimpanan agar buah lebih tahan lama (Tekstur Aril buah) dan bisa dikonsumsi disarankan menggunakan wadah karung.

2. Dilakukannya penelitian lebih lanjut tentang kandungan kimia buah rambutan yang telah disimpan, untuk mengetahui pada hari keberapa gizi rambutan lebih banyak guna mendapatkan keseluruhan manfaat dari gizi rambutan.

\section{UCAPAN TERIMA KASIH}

Pada kesempatan ini penulis menyampaikan terima kasih kepada Ibu Ir. T. Rosmawaty, M.Si dan Ibu Mardaleni, Sp., M.Sc yang telah membimbing saya dalam pelaksanaan penelitian ini serta teman-teman yang membantu dalam tahap penelitian ini.

\section{DAFTAR PUSTAKA}

Broto, W. 1991. Kajian Morfologis, Anatomis dan Histologis Buah Rambutan (Nephelium lappaceum, Linn) cv. "Binjai". Jurnal Hortikultura I A): 1-7.

Casas, A., Caballero, J., Valeinte-Banuet, A., Sorianto, J.A., and Davila, P. 1999. Morphological variation and the process of domestocation of Stenocereus stellatus (Cactaceae) in Central Maexico. American Journal of Botany (86):522533.

Frisilia, S., Nery Sofiyanti, Fitmawati. 2013. Analisis Hubungan Kekerabatan Rambutan (Nephelium Lappaceum L.) Di Kabupaten Kampar Provinsi Riau Berdasarkan Karakter Morfologi. Karya Ilmiah. Universitas Riau.

Haryanti, T., Sabari, S., Purwati, D., Soemarno,H.S. dan Sunarmani. 1991. Kajian Mutu Buah Mangga Malam Asal Yogyakarta Pada Beberapa Tingkat Ketuaan Pemanenan Jakarta: Jurnal Hortikultura I (I): 57 - 60.

IPGRI. 2003. Descriptors for Rambutan (Nephelium lappaceum). International Plant Genetic Resource Istitute, Rome, Italy.

Lydia, dkk. 2001. Ekstraksi Dan Karakterisasi Pigmen Dari Kulit Buah Rambutan (Nepheliumla Ppaceumy) Var. Binjai. 
Malang: Jurnal Teknologi Pangan dan Gizi. Vol 2, Nomor 1: 1-16.

Mahisworo, dkk. 1991. Bertanam Rambutan. Penebar Swadaya: Jakarta. cet ke-3. (25 Februari 2017).

Muchtadi, T. R. dan Sugiyono. 1992. Ilmu Pengetahuan Bahan Pangan. Departemen Pendidikan dan Kebudayaan. Direktorat Jenderal Pendidikan Tinggi. Pusat Antar Universitas Pangan dan Gizi. IPB. 412 hal.

Noor Harini, 1993. Pengaruh Umum Panen dan Suhu Pendinginan Terhadap Perubahan Beberapa Sifat Fisikokimia Jagung Manis Segar Selama Periode Penyimpan Tesis Yogyakarta: Program Pasca Sarjana. UGM.

Prihanta, W. 2004. Identifikasi Pteridophyta Sebagai Database Kekayaan Hayati Di Lereng Gunung Arjuno, Universitas Muhammadiyah Malang, Malang.

Retnoningsih, A. 2003. Introductory Science Philosophy. Institut Pertanian Bogor. Bogor.

Simmons, S.L., Hofman, P.J., Whiley, A.W. and Hetherington, S.E. (1998). Effects of leaf to fruit ratios on mango (mangifera indica 1. 'kensington') fruit growth, nutrition and quality. Acta Hortic. 464, 47-52DOI: 10.17660/actahortic.1998.464.3.

Siti Nurhayati. 2004. Kajian Sifat Fisik, Kimia Dan Fisiologi Terhadap Beberapa Tingkat Kematangan Buah Rambutan Varietas Si Macan Di Kabupaten Gunung Kidul Yogyakarta. Yogyagarta: Jurnal Matematika, Sains Dan Teknologi. Vol. 5 No. 2, 85-96.

Soenaryono, H., Moehd. Baga Kalie, A. Basuki. 1982. Evaluasi Plasma Nutfah Rambutan bermutu dan Berpotensi Tinggi. Buletin Penelitian Hortikultura. Vol. IX. No. 04. Lembang. Balai Penelitian Hortikultura, Lembang.

Sosrodihardjo, S. 1991. Quality evaluation of rambutan fruit cv. Rapiah at several stages of maturity. Jurnal Hortikultura Indonesia. ISSN: 0853-7097. Frekuensi: Triwulan.

Stover, R.H. and N.W. Simmonds. 1987. Bananas. Harlow, Essex, England: Longman Scientific \& Technical; New York: Wiley, 1987.
Victoria Hawarima dan Ety Apriliana. 2016. Kandungan Buah Rambutan (Nephelium lappaceum L.)sebagai Antibakteri terhadap E. coli Penyebab Diare. Lampung: Jurnal Biologi Medik, Fakultas Kedokteran Universitas Lampung. Vol. 5, No. 2: 126-130.

Wills,RH., TH. Lee, D. Graham, WBM. Glasson, EG.1981. PostharvestAnInteroduction To The Physiology and Handling of Fruit and Vegetables.Australia: NSW University Press. 